„Bohemistyka” 2021, nr 3, ISSN 1642-9893

\title{
$\begin{array}{lllllll}\mathbf{K} & \mathbf{R} & \mathbf{O} & \mathbf{N} & \mathbf{I} & \mathbf{K} & \mathbf{A}\end{array}$
}

Jiří HASIL

DOI: $10.14746 /$ bo. 2021.3 .14

Unierzita Karlova

\section{Ohlédnutí za Milanem Šárou a Janem Holubem}

Konec zimy a nástup jara roku 2021 přinesl dvě smutné zprávy. V této době opustily řady českých učitelů češtiny pro cizince dvě zakladatelské osobnosti tohoto oboru - Milan Šára a Jan Holub, dlouholetí členové akademické obce Filozofické fakulty Univerzity Karlovy v Praze a učitelé Ústavu bohemistických studií, kteří se nesmazatelným písmem zapsali i do historie pražské Letní školy slovanských studií.

Doc. PhDr. Milan Šára se narodil 29. 10. 1932 v Praze. Po absolvování oboru čeština - angličtina na pražské Filozofické fakultě nastoupil v roce 1958 jako učitel do Studijního střediska Univerzity 17. Listopadu v Mariánskách Lázních a začal se věnovat výuce češtiny pro cizince. Setkal se zde s řadou inspirativních kolegů, především s Antonínem Bytlem a Helenou Confortiovou. A společně promýšleli nové didaktické postupy, jak co nejefektivněji a nejrychleji připravit zahraniční studenty ke studiu na českých vysokých školách. V roce 1963 přešel na pražskou Filozofickou fakultu a nastoupil jako odborný asistent na tehdejš́ katedru češtiny pro cizince a na tomto pracovišti (měnícím svůj název a statut podle nastalé společenské situace) působil až do svého penzionování v roce 2005. Získal titul PhDr., docentem mohl být jmenován až v roce 1990. V letech 1989-2005 zastával funkci zástupce ředitele Ústavu bohemistických studií.

Milan Šára vyučoval praktické jazykové kurzy a vedl přednášky a semináře zaměřené zejména na syntax českého jazyka. Po roce 1989 navázal na Hanu Hrdličkovou z Ústavu českého jazyka a teorie komunikace FF UK a otevřel i semináŕ didaktiky češtiny pro cizince. Popis češtiny jako cizího jazyka promýšlel již od šedesátých let vždy prizmatem didaktiky tohoto oboru, a to s hlubokou znalostí odborné lingvistické i didaktické literatury domácí i zahraniční, „východní” i „západní”. Především pro zahraniční bohemisty se mu jevilo pro výuku české syntaxe jako velmi př́nosné pojetí britského lingvisty Michaela Alexandera Kirkwooda Hallidaye, zakladatele tzv. funkční systémové lingvistiky. Výsledkem tohoto Šárova pohledu na českou syntax je 
jednak skriptum A Basic Course of Czech Syntactic Structures, dnes bohužel poněkud pozapomenuté, jadnak jeho výklad české gramatiky v popisu češtiny na úrovni B2 dle Společného evropského referenčního rámce pro jazyky. Svůj př́istup k prezentaci české syntaxe prosadil i do kolektivní učebnice Czech 1, 2, A Multi-Level Course for Advanced Learners. Jako vedoucí autorského kolektivu Milan Śára výrazně ovlivnil i podobu popisu češtiny na úrovni B1 dle SERR. A opomenout nelze ani Šárův vklad do kolektivního monumentálního Slovníku české frazeologie a idiomatiky.

Studenti vždy obdivovali Milana Šáru pro jeho široký lingvistický rozhled i pro jeho hluboké znalosti české a evropské kultury a umění. Kolegové si ho vážili jako čestného, laskavého a přátelského kolegu a oceňovali též jeho prátelský, ale náročný prístup ke studentům.

PhDr. Jan Holub zemřel po dlouhé nemoci 22. března 2021. Bylo mu 83 let.

Pražský rodák (nar. 6. 12. 1937) vystudoval anglistiku, bengálštinu a bohemistiku na FF UK v Praze a hned po studiích se začal věnovat výuce češtiny pro cizince, zprvu v letech 1962-1964 ve studijním středisku Univerzity 17. listopadu v Dobrušce a od roku 1964 až do odchodu do důchodu na pražské Filozofické fakultě Univerzity Karlovy. Působil v Ústavu bohemistických studií a od roku 1965 soustavně věnoval své síly a pedagogické mistrovství Letní škole slovanských studií, zpočátku jako lektor a později též jako vedoucí lektorského sboru, tajemník a zástupce ředitele. Nelze zapomenout, s jakou noblesou a rozvahou vždy dokázal sestavit pro jednotlivé běhy letní školy lektorský sbor sestavený z mladších nadšených a inovativních lektorù a z lektorů zkušených, starších, kteří tak mohli své zkušenosti předávat pod Holubovým dohledem mladším.

Brzy se na svém pracovišti etabloval jako úspěšný, náročný a oblíbený učitel zahraničních studentů a vyrostl vedle Jiř́iho Hronka, Františka Čermáka, Milana Šáry, Aleny Trnkové, Kamily Filipové jako výrazná osobnost druhé generace učitelů češtiny pro cizince na FF UK. Své zkušenosti a znalosti záhy začal vkládat do řady úspěšných učebnic češtiny pro cizince. Za všechny zde jmenujme např́íklad velm úspěšnou učebnici Czech for Beginners, z níž se učili cizinci česky nejen na FF UK, ale i na jiných českých univerzitách, ale i na četných bohemistických pracovištích zahraničních, a skriptum Syntagmatika a paradigmatika českého slova, které napsal spolu s Františkem Čermákem.

Své didaktické zkušenosti promítl jako spoluautor i do publikace Prahová úroveň, čeština jako cizí jazyk, tj. do popisu češtiny na úrovni B1 podle Společného evropského referenčního rámce pro jazyky a jako vedoucí autorského kolektivu, který vypracoval popis češtiny na úrovni B2. Jan Holub se od počátku aktivně zapojil jako rozený kolektivní hráč do náročné práce, jejímž výsledkem je kolektivní pětidílny Slovník české frazeologie a idiomatiky, vedoucím autorského kolektivu byl František
Čermák. Holubův podíl na konečné verzi rukopisu v průběhu let rostl a poslední díl Onomaziologický slovník je z velké části jeho dílem. První čtyři díly slovníku se dočkaly již druhého vydání.

Holubovy kolegy zpráva o jeho odchodu hluboce zarmoutila. Odešla výrazná osobnost nejen Ústavu bohemistických studií. Filozofická fakulta jeho odchodem ztratila oddaného skromného pracovníka, odborářského funkcionáře, výrazného učitele, pro kterého práce se studenty a pro studenty stála vždy na prvním místě.

I po odchodu do důchodu Jan Holub udržoval kontakt se svým pracovištěm a se svými spolupracovníky, kteří na něho vždy budou vzpomínat jako na spolehlivého vzdělaného a přátelského kolegu, který byl vždy ochoten předávat své zkušenosti mladším, jako na dobrého a veselého člověka hledajícího smysl svého života v práci pro rozvoj oboru i pracoviště a v péči a starost o rodinu.

Šárovy a Holubovy žáky najdeme doslova po celém světě. Oba svou prací pedagogickou i badatelskou vyorali hlubokou brázdu, na niž bude možno ještě dlouhou dobu navazovat.

Čest jejich památce! 